\title{
Public Welfare Development Strategy of Pre-school Education based on Government Responsibilities
}

\author{
Chengyun Zhang \\ Baicheng Institute of Education, Baicheng City, Jilin Province, 137000, China
}

Keywords: Government Responsibility, Pre-school Education, Public Welfare, Development Strategies.

\begin{abstract}
At present, there are many problems of government responsibility in the process of pre-school education popularity, such as insufficient financial input, few public kindergartens, inadequate pre-school education agency, absence of government supervision, a lacking of government accountability and etc.. Therefore, the definition and implementation of government responsibility is the key to speed up the popularization of pre-school education, and to improve the quality of pre-school education, which should be paid great attention by governments at all levels. Based on the author's learning and practical experience, this paper first analyzed the phenomenon of government responsibility anomie in the popularization of pre-school education, and then put forward the idea of public welfare development of pre-school education based on government responsibility.
\end{abstract}

\section{Introduction}

National Plan for Medium and Long Term Educational Reform and Development has clearly put forward the main responsibility of the government for the popularization of pre-school education. It is of great practical significance today that pre-school education is in urgent need of development. In the process of popularizing pre-school education, the problems caused by the anomie of government responsibility have become a serious obstacle to the development of pre-school education. Therefore, the importance and urgency of the popularization of pre-school education should be realized from the strategic and overall level, and the responsibility of governments at all levels should be implement as well to promote a sound and rapid development of pre-school education.

\section{The Phenomenon of Government Responsibility Anomie}

Insufficient financial input. For a long time, the lack of understanding of pre-school education by all levels of government has led to the pre-school education become a "short board" of our education system, and the serious shortage of government investment is the fundamental reason restricting the development of pre-school education. The proportion of financial pre-school education funds in GDP has been maintained at $0.03 \% \sim 0.05 \%$, and the proportion of financial pre-school education funds in the country has been at a low level as well. Compared with other stages of education, pre-school funding is also the least. In our country, 9.5\% of pre-school children who have received education dominate only $1.3 \%$ of the total educational funds. In addition, pre-school financial funds have been included in the primary and secondary education budget. Therefore, this situation weakens the government's input responsibility, which leads to the lack of pre-school education funds and restricts the development of pre-school education.

A lack of public kindergartens. Since 1990s, the public kindergartens have been transformed into private ones under the structural reform, which exists in different parts of the country in varying degrees. The governments and state-owned enterprises' kindergartens began to peel off, as well as the collective kindergartens, which are replaced by private kindergartens. Because the government's understanding of pre-school education is not in place, public kindergarten is becoming increasingly less. Therefore, the socialization and marketization of pre-school bring a 
series of negative effects, such as chaotic managements and vicious price competitions. For example, substandard kindergarten-running conditions, poor education qualities, and even the health and life safety issues.

Unsound and chaotic pre-school education managements. First of all, the pre-school education administration is not sound. Many full-time staffs regard the pre-school education as their main duties, but they still participate in managements of primary and junior educations. Even for some full-time pre-school administrators, pre-school education managements accounts for only $1 / 3$ or $1 / 4$ of their work. This situation seriously weakens the leadership and management of pre-school educations, so that the management responsibility is difficult to be implemented. Furthermore, the management of pre-school education is chaotic. First, there exist unclear responsibilities, long management and illegal approval phenomenon. Industry and commerce, civil affairs and other relevant departments examine and approve kindergartens beyond authorities. Another is that most of the private kindergartens are in states of neglect actually. .According to the principle of "who approves, who manages, who is responsible", Some of kindergartens approved by the department of education and social education office in a state of neglect, as well as kindergartens approved by non-education departments.

The absence of government supervision and the lack of accountability. To date, the government supervision institutions of pre-school education and the administrative departments of education have not been clear about their responsibilities, so that it is difficult to put their responsibilities in place. Thus, the government supervision institutions of pre-school education are tough to play the role of real supervisions, leading to lack of supervisions. Therefore, all levels of government's compulsory assessment indicators of compulsory educations have "crowding out" effect on pre-school education. Many local governments have given up pre-school educations to reach the standards of compulsory educations. Due to the lack of pre-school education supervision regulations, there is a lack of specific, operational and punitive measures or accountability system in the process of educational supervision at all levels, which cause seriously flawed government's pre-school education supervisions and evaluations.

\section{Public Welfare Development of Pre-school Education based on Government Responsibility}

Formulating development plans and adjusting the structural system. Based on the imbalance and gap in the development of preschool education in urban and rural areas, governments at all levels must consider the changing trends of children population and grasp the people's needs of the pre-school education accurately, Then, the governments should make a scientific development planning, modulate the structure of preschool education in urban and rural areas rationally, increase the policy support of private kindergarten, weak kindergarten, kindergarten in remote rural areas and migrant children's kindergarten, so as to ensure the funds of construction, education facilities, teacher treatments, teacher training organizations and professional qualification evaluation. Furthermore, the proportion of public gardens should be expanded, and the number of public gardens and their undertakings will be increased through new construction and reconstruction, so as to ensure the basic popularization of pre-school education.

Increasing capital inputs \&allocating resources rationally. On the one hand, a protection mechanism for investment in pre-school education should be established with the support of public finance. Governments should include preschool education funds in government budget, and arrange a certain proportion of pre-school education special funds every year, to ensure that the pre-school education financial funds is more and more rationalized, and the pre-school education financial funds could be prepared in one step. On the other hand, the whole society should be mobilized to support pre-school education, perfect the social forces to set up educational system and policy, improve the social resources of preschool education continuously, encourage social forces to organize high-quality kindergartens and introduce preferential policy about land planning and tax revenue collection.

Improving management systems \&strengthening control policies. Based on chaotic situation of pre-school education management, it is urgent to explore new scientific management mechanism, 
strengthen the pre-school education management, perfect the management mechanism, and attach assessment, supervision, professional guidance and training into management, to achieve integrated management. At the same time, it is essential to standardize the examination and approval of private kindergartens, definite responsibilities of regulators and strengthen the management, guidance and support of private kindergartens. In addition, the administrative department of education should strengthen its sense of responsibility to standardize the institutions for pre-school education. For example, kindergartens should be gradually reformed and put into charge of local education administration departments. Furthermore, the support for private kindergartens by governments should be administrated by education administration departments, which are assisted by local Civil affairs, industry and commerce, taxation, price departments. At last, kindergartens held by Own revenue and expenditure should be adjusted to territorial management, or local education administration departments.

Maintaining educational equity \&improving education orientation. The public welfare of pre-school education regards fair as its value orientation, requiring the governments embody the fair and efficiency principle during pre-school education period. Specifically, governments should ensure that each school-age child has a equal access to education. However, for disadvantaged children, it is not enough to emphasize equal treatments, and the priority support strategy should be implemented by the positive difference principle so as to achieve the educational equality. Therefore, a social security system should be established by governments, government organizations and NGOs to Support vulnerable groups, so that all children who meet the special funding standards could receive long-term, non-differential financial aids.

Strengthening quality supervision \&improving service system. Focusing on the situation of chaotic private kindergarten management and decline of education quality, educational administrative departments should build a view of pre-school educational quality and take effective measures, to establish the inspection and evaluation standards of educational quality, and implement strict pre-school education quality responsibility and accountability system. Furthermore, the pre-school education service system should be gradually improved to promote the active and orderly development of pre-school education.

Improving laws and regulations \&providing institutional guarantee. Education legislation is an important means of national regulation and management of education, and the regulation of management and operation of the educational system is mainly achieved by laws and regulations as well. It is urgent to solve many problems in the development of preschool education, respectively are improving the level of preschool education legislation, giving the pre-school education legal status and formulating scientific, appropriate and powerful laws.

\section{Summary}

Several approaches are proposed to enhance the public welfare of pre-school education. Firstly, the government should formulate a plan for the pre-school education development scientifically, adjust the structure of pre-school education system, and ensure the coordinated development of public kindergartens. Secondly, the funds and resources of pre-school education should be strengthened to set up the investment guarantee mechanism and the various funds supervision mechanisms with the support of public finance, in which way the whole society is mobilized to support pre-school education and perfect the education system and policy. Thirdly, the management system and dynamics of regulation and control should be improved, so that all kinds of pre-school education institutions could be reformed to be administrated by local educational administrative departments. Fourthly, all kinds of disadvantaged children should be support to receive pre-school education by a social equity, which fully exhibits the compensation function of pre-school education. Fifthly, quality supervision should be strengthened to establish inspection and evaluation standards of educational quality. At last, a national preschool education law should be formulated as soon as possible, in which way the pre-school education could develop according to laws, and realize the healthy and orderly preschool education development eventually. 


\section{References}

[1] Jianchao Chen. The Research on Motivation and Reform Path of Government Purchasing Pre-school Education Service [J]. Education Review, 2016, (10): 62-65.

[2] Pingchuan Wu. The Research on Government Responsibility of Pre-school Education Investments in China [J]. Journal of Educational Studies, 2014, (03): 94-99.

[3] Xianbing Zhang. On Public Interest of Pre-school Education and the Responsibility of Our Government [J]. Journal of Northeast Normal University (Philosophy and Social Sciences), 2012, (05): 188-191.

[4] Yan Li. Analysis of the Public Welfare and Government Responsibility of Pres-chool Education [J]. Business, 2012,(11):168.

[5] Shenghe Gu. Strategies for Local Governments to Promote the Development of Regional Preschool Education [J]. Education Research Monthly, 2011,(05):75-76.

[6] Lijuan Pang, Xiaoyu Han. Legislation of China’s Pre-school Education: Reflection and Progress. Journal of Beijing Normal University (Social Sciences), 2010, (05):14-20.

[7] Zhanli Liu. Pre-school Education must Maintain the Two Basic Characteristics of Instructiveness and Public Interest [J]. Educational Research,2009,(05):31-36. 